\title{
Profil Pasien Geriatri dengan Ulkus Dekubitus di RSUP Dr. M. Djamil
}

\author{
Sasqia Trizolla ${ }^{1}$, Roza Mulyana ${ }^{2}$, Nurhayati ${ }^{3}$ \\ ${ }^{1}$ Fakultas Kedokteran Universitas Andalas, Padang \\ ${ }^{2}$ Subbagian Geriatri Bagian IImu Penyakit Dalam Fakultas Kedokteran Universitas Andalas/RSUP Dr. M. Djamil Padang \\ ${ }^{3}$ Bagian Parasitologi Fakultas Kedokteran Universitas Andalas, Padang
}

\section{A B S T R A C T}

\begin{abstract}
Latar Belakang. Ulkus dekubitus atau luka tekan merupakan kerusakan kulit dan jaringan lunak akibat tekanan terusmenerus pada area tonjolan tulang. Kejadian ulkus dekubitus banyak ditemukan pada usia lanjut dengan kondisi imobilisasi. Pasien usia lanjut dengan beberapa penyakit disebut dengan pasien geriatri.

Objektif. Tujuan penelitian ini adalah mengetahui profil pasien geriatri dengan ulkus dekubitus yang dirawat di RSUP Dr. M. Djamil Padang tahun 2016 - 2019.
\end{abstract}

Metode. Penelitian ini menggunakan metode deskriptif observasional dengan pengambilan data sekunder dari rekam medis. Jenis sampel yang digunakan adalah pasien dengan usia lanjut yang memiliki data rekam medis yang lengkap yaitu: stadium klinis ulkus, penyebab imobilisasi, lama imobilisasi, dan penyakit penyerta. Data diolah dan disajikan dalam bentuk tabel distribusi frekuensi.

Hasil. Hasil penelitian ini menunjukkan 38,8\% pasien berada pada kelompok umur 60 - 69 tahun dan 74,6\% berjenis kelamin perempuan. Variasi stadium klinis terbanyak adalah stadium 2 (43,3\%). Penyakit neurologis merupakan penyebab imobilisasi terbanyak berdasarkan faktor intrinsik $(38,8 \%)$ dan trauma berdasarkan faktor ekstrinsik. Lama imobilisasi pasien tersingkat 7 hari dan terlama 10 tahun. Penyakit paru menjadi penyakit penyerta terbanyak pada pasien geriatri dengan ulkus dekubitus.

Kesimpulan. Sebagian besar pasien berada pada kelompok usia lanjut muda dan berjenis kelamin perempuan. Stadium terbanyak adalah stadium 2 yang disebabkan oleh penyakit neurologi dan trauma. Lama imobilisasi tersingkat ditemukan 7 hari dan terlama 10 tahun. Penyakit penyerta terbanyak adalah penyakit paru.

Kata kunci: Ulkus dekubitus, pasien geriatri, imobilisasi

Background. A pressure ulcer is damage to the skin and soft tissue due to continuous pressure on the area of the bone prominent. The incidence of pressure ulcers is found in the elderly with immobilization. Elderly patients with several diseases are called geriatric patients.

Objective. This study was aimed to determine the profile of geriatric patients with pressure ulcers that are hospitalized at RSUP Dr. M. Djamil Padang year 2016 - 2019.

Method. The method used descriptive observational by collecting secondary data from medical records. The samples are taken from elderly patients who had intact data on medical records: clinical-stage, causes of immobilization, immobilization duration, and comorbid disease. The data is shown in the frequency distribution table.

Result. The results showed that $38.8 \%$ of patients were mostly in the group of age $60-69$ years and $74.6 \%$ are female. The most variation of clinical-stage was stage 2 (43.4\%). Neurological disease was the most common cause of immobilization (38.8\%). The shortest periods of immobilization of patients 7 days and the longest 10 years. Lung disease was the most common comorbidities found in geriatric patients with a pressure ulcer.

Conclusion. Most of the patients were in the young elderly age group and are female. The most common stage was stage 2 caused by neurological disease and trauma. The shortest immobilization time was found 7 days and the longest 10 years. Most comorbidities are lung disease.

Keyword: Pressure ulcer, geriatric patients, immobilization

\section{Apa yang sudah diketahui tentang topik ini?}

Imobilisasi merupakan salah satu faktor terjadinya ulkus decubitus.

\section{Apa yang ditambahkan pada studi ini?}

Sebagian besar pasien berada pada kelompok usia lanjut muda dan berjenis kelamin perempuan. Stadium terbanyak adalah stadium 2 yang disebabkan oleh penyakit neurologi dan trauma. Lama imobilisasi tersingkat ditemukan 7 hari dan terlama 10 tahun. Penyakit penyerta terbanyak adalah penyakit paru.

\section{CORRESPONDING AUTHOR}

Name: Sasqia Trizolla

Phone: +6282387424221

E-mail: sasqiatrzl08@gmail.com

\section{ARTICLE INFORMATION}

Received: September $23^{\text {rd }}$, 2020

Revised: October $15^{\text {th }}, 2020$

Available online: October $31^{\text {st }}$, 2020 


\section{Pendahuluan}

Ulkus dekubitus merupakan salah satu tantangan kesehatan utama di dunia yang mengenai banyak orang dan berakhir pada pengeluaran biaya kesehatan yang sangat besar. ${ }^{1}$ Ulkus dekubitus atau yang disebut juga dengan pressure ulcer merupakan kerusakan/kematian kulit dan jaringan dibawahnya akibat adanya tekanan pada suatu area yang terus-menerus sehingga mengakibatkan gangguan sirkulasi pada daerah tersebut. ${ }^{2}$ Ulkus juga bisa terjadi ketika seseorang bertahan pada satu posisi untuk waktu yang lama seperti berbaring di tempat tidur, kemudian bagian tersebut menjadi iskemik karena tekanan terus-menerus dan konstan. Area tulang yang menonjol di tubuh merupakan bagian yang sering terkena ulkus dekubitus. ${ }^{3}$

Ulkus dekubitus menjadi beban utama dari sebuah penyakit dan mengakibatkan berkurangnya kualitas hidup penderita dan juga pengasuhnya. Orang yang paling rentan terkena adalah yang berusia di atas 75 tahun seiring dengan peningkatan usia. ${ }^{5}$ Proses penuaan dan faktor lingkungan dapat merusak kulit dan meningkatkan perkembangan ulkus dekubitus. Perubahan kulit yang berkaitan dengan usia berupa penipisan lapisan dermo-epidermal dan pergantian sel kulit yang lambat, berkurangnya elastisitas, penipisan lapisan subkutan, berkurangnya massa otot secara keseluruhan (sarkopenia), dan berkurangnya perfusi vaskuler serta oksigenasi. ${ }^{6}$

Kejadian yang paling banyak ditemukan adalah pada usia lanjut dengan kondisi imobilisasi. ${ }^{5}$ Pasien yang mengalami imobilisasi dengan BMI yang rendah, kadar albumin dan hemoglobin, marker inflamatori yang tinggi (CRP dan ESR) disertai dengan ketidakstabilan hemodinamik serta adanya komplikasi yang kronik dapat memicu terjadinya ulkus dekubitus. ${ }^{7}$

Data yang menunjukkan prevalensi ulkus dekubitus belum diketahui secara pasti. Berdasarkan penelitian dari para ahli, diperkirakan terdapat sekitar 9,2\% kejadian ulkus dekubitus dari seluruh tempat rawatan di Jerman. Diantaranya $5-10 \%$ berada di rumah sakit, 30\% yang berasal dari klinik geriatri dan panti jompo, dan sekitar $20 \%$ dirawat di rumah oleh perawat. Data ini berdasarkan 550.000 penderita ulkus dekubitus dari 2,3 juta orang yang menjalani rawatan. ${ }^{8}$
Prevalensi ulkus dekubitus yang didapatkan dibeberapa negara di Asia seperti di Singapura $(18,1 \%)$, Malaysia $(15,5 \%)$, Jepang $(9,8 \%)$, dan China (1,8\%). ${ }^{9}$ Penelitian kasus di Indonesia yang dilakukan di Kota Bandung didapatkan sebanyak $10,8 \%$ kasus. Sebanyak $51,4 \%$ diantaranya ulkus dekubitus derajat $1,17,1 \%$ derajat 2, $15,7 \%$ derajat 3 dan sebanyak $5,7 \%$ diduga sebagai cedera jaringan yang dalam. Sedangkan derajat 4 dan yang tidak dapat diklasifikasikan tidak ditemukan. Lokasi ulkus yang paling dominan pada stadium 1 terdapat pada lutut $(21,4 \%)$ dan kaki $(12,9 \%)$, sedangkan lokasi tersering selain dari stadium 1 terdapat pada sakrum $(25,9 \%)$, bahu $(25,9 \%)$, dan panggul $(22.2 \%) .{ }^{10}$

Pasien geriatri adalah pasien usia lanjut atau usila (usia lebih dari 60 tahun) dengan multipenyakit dan/atau gangguan akibat penurunan fungsi organ, psikologi, sosial, ekonomi, dan lingkungan yang membutuhkan pelayanan kesehatan terpadu dengan pendekatan multidisiplin yang bekerja secara interdisiplin. ${ }^{11}$ Pada geriatri dengan imobilisasi yang lama akan menyebabkan aliran darah kapiler ke jaringan mudah terhambat karena adanya tekanan luar yang lebih besar daripada tekanan darah kapiler khusunya pada bagianbagian tubuh yang menonjol. Kemudian jaringan tersebut akan hipoksia dan lama-kelamaan berujung menjadi jaringan yang nekrotik. ${ }^{8}$

Penelitian yang dilakukan di RSUP Dr. M. Djamil Padang pada tahun 2011-2013 didapatkan penderita ulkus dekubitus yang didominasi oleh pasien perempuan sebanyak $57 \%$ dengan kelompok umur terbanyak yaitu usia lanjut $>59$ tahun dan pada tahun 2015 didapatkan pasien geriatri dengan ulkus dekubitus didominasi lakilaki sebanyak $65,2 \%$ dengan kelompok umur $\geq 70$ tahun dengan persentase $51,7 \% .12,13$ Serta didapatkan onset ulkus $\leq 2$ minggu rawatan dengan persentase $79 \% .{ }^{12}$ Sedangkan penelitian yang dilakukan di RSUD Arifin Achmad Provinsi Riau didapatkan hari pertama muncul ulkus ratarata pada hari ke-9 dan kebanyakan muncul pada hari ke-7.14

Berdasarkan uraian diatas penulis berpendapat bahwa perlunya dilakukan penelitian ini di RSUP Dr. M. Djamil yang merupakan rumah sakit rujukan dikarenakan jumlah pasien dengan ulkus dekubitus cukup banyak. Selain itu masih banyak pengasuh atau keluarga pasien yang 
kurang mendapat informasi dan pengetahuan tentang kejadian ulkus dekubitus sehingga angka kejadian ulkus semakin meningkat. Ulkus dekubitus memberi dampak besar terhadap perubahan kondisi kesehatan penderitanya mulai dari aspek sosial, finansial, morbiditas, mortalitas, dan kualitas hidup. Oleh karena itu penulis tertarik untuk melakukan penelitian dengan judul Profil Pasien Geriatri dengan Ulkus Dekubitus yang dirawat di RSUP Dr. M. Djamil Padang tahun 2016-2019.

\section{Metode}

Penelitian ini dilasanakan pada Januari 2020 Juli 2020 di bagian rekam medik RSUP Dr. M. Djamil Padang dengan menggunakan teknik total sampling pada pasien geriatri dengan ulkus dekubitus.

Populasi penelitian ini adalah seluruh pasien dengan ulkus dekubitus yang berusia $\geq 60$ tahun yang dirawat di RSUP Dr. M. Djamil Padang tahun 2016-2019 dengan pengumpulan data usia, jenis kelamin, penyakit penyerta, stadium klinis, lama imobilisasi dan penyebab imobilisasi.

Sampel penelitian yang dipilih adalah bagian dari populasi penelitian yang memenuhi kriteria inklusi yaitu pasien dengan ulkus dekubitus yang berusia $\geq 60$ tahun, dan pasien dirawat inap di RSUP Dr. M. Djamil Padang tahun 2016 - 2019. Dan eksklusi yaitu pasien yang tidak memiliki data yang lengkap.

Analisis data yang dilakukan adalah analisis data univariat pada setiap variabel dengan menggunakan program komputer. Pada analisis univariat, data yang berskala nominal disajikan dalam tabel distribusi frekuensi.

\section{Hasil}

Penelitian ini merupakan penelitian deskriptif dengan mengambil data sekunder berupa rekam medis pasien usia lanjut yang didiagnosis menderita ulkus dekubitus dan dirawat di RSUP Dr. M. Djamil Padang periode 2016-2019 dengan teknik pengambilan sampel total sampling. Jumlah pasien usia lanjut yang tercatat menderita ulkus dekubitus sebanyak 125 orang, sebanyak 13 orang diantaranya tidak ditemukan data rekam medisnya, sebanyak 45 orang tidak memenuhi kriteria inklusi sehingga jumlah sampel yang memenuhi kriteria adalah 67 sampel.

\section{Distribusi Pasien Geriatri dengan Ulkus Dekubitus Berdasarkan Kelompok Usia dan Jenis Kelamin}

Tabel 1. Dstribusi Pasien Geriatri dengan Ulkus Dekubitus Berdasarkan Kelompok Usia dan Jenis Kelamin

\begin{tabular}{cccc}
\hline \multirow{2}{*}{$\begin{array}{c}\text { Kelompok } \\
\text { Usia }\end{array}$} & \multicolumn{2}{c}{ Jenis Kelamin } & Total (\%) \\
\cline { 2 - 3 } & Laki-laki & Perempuan & \\
\hline $60-69$ tahun & 7 & 19 & $26(38,8 \%)$ \\
$70-79$ tahun & 7 & 10 & $17(25,4 \%)$ \\
$\geq 80$ tahun & 3 & 21 & $24(35,8 \%)$ \\
\hline Total & 17 & 50 & 67 \\
& $(25,4 \%)$ & $(74,6 \%)$ & $(100 \%)$ \\
\hline
\end{tabular}

Pada tabel 1 di atas didapatkan distribusi pasien geriatri dengan ulkus dekubitus yang dirawat di RSUP Dr. M. Djamil Padang tahun 2016 - 2019 paling banyak ditemukan pada rentang umur 60 - 69 tahun dengan jumlah 26 orang (38,8\%) kemudian diikuti kelompok umur $\geq 80$ tahun dan kelompok umur 70 - 79 tahun. Pasien perempuan lebih banyak ditemukan daripada laki-laki dengan jumlah pasien perempuan sebanyak 50 orang $(74,6 \%)$ dan laki-laki sebanyak 17 orang $(25,4 \%)$.

\section{Variasi Stadium Klinis Ulkus Dekubitus pada Pasien Geriatri}

Tabel 2. Variasi Stadium Ulkus Dekubitus pada Pasien Geriatri

\begin{tabular}{ccc}
\hline Stadium Klinis & f & \% \\
\hline Stadium 1 & 2 & 3 \\
Stadium 2 & 29 & 43,3 \\
Stadium 3 & 15 & 22,4 \\
Stadium 4 & 5 & 7,5 \\
Tidak diktehui & 14 & 20,9 \\
Ulkus multipel & 2 & 3 \\
\hline Total & 67 & 100 \\
\hline
\end{tabular}

Penelitian ini mendapatkan variasi stadium klinis ulkus dekubitus pada geriatri yang terbanyak yaitu stadium 2 sebanyak 29 orang $(43,3 \%)$ dan diikuti stadium 3 sebanyak 15 orang $(22,4 \%)$.

\section{Penyebab Imobilisasi pada Pasien Geriatri dengan Ulkus Dekabitus berdasarkan Faktor Resiko}

Pada penelitian ini ditemukan penyebab imobilisasi terbanyak dari faktor risiko intrinsik atau yang berasal dari tubuh pasien itu sendiri. Penyakit neurologis menjadi penyebab imobilisasi terbanyak pertama dengan jumlah 26 orang sedangkan penyebab imobilisasi berdasarkan faktor risiko ektrinsik didapat trauma sebanyak 2 
orang dan postoperative hip replacement sebanyak 1 orang. Sebanyak 15 orang tidak diketahui penyebab imobilisasinya.

Tabel 3. Penyebab Imobilisasi pada Pasien Geriatri dengan Ulkus Dekubitus berdasarkan Faktor Risiko

\begin{tabular}{|c|c|c|}
\hline Penyebab Imobilisasi & f & $\%$ \\
\hline \multicolumn{3}{|l|}{ Faktor intrinsik } \\
\hline $\begin{array}{l}\text { Gangguan motorik: fraktur, OA, } \\
\text { penyakit tulang dan sendi }\end{array}$ & 15 & 22,4 \\
\hline $\begin{array}{l}\text { Penyakit neurologis: stroke, } \\
\text { hemiplegi }\end{array}$ & 26 & 38,8 \\
\hline Penyakit kardiovaskular & 1 & 1,5 \\
\hline $\begin{array}{ll}\text { Kelemahan } & \text { umum: } \\
\text { keganasan,malnutrisi,CKD } & \end{array}$ & 7 & 10,4 \\
\hline \multicolumn{3}{|l|}{ Faktor ekstrinsik } \\
\hline Trauma & 2 & 3 \\
\hline Post operatif hip replacement & 1 & 1,5 \\
\hline Tidak diketahui & 15 & 22,4 \\
\hline Total & 67 & 100 \\
\hline
\end{tabular}

\section{Lama Imobilisasi pada Pasien Geriatri dengan Ulkus Dekubitus}

Tabel 4. Lama Imobilisasi pada Pasien Geriatri dengan Ulkus Dekubitus

\begin{tabular}{lcccc}
\hline \multicolumn{1}{c}{ Variable } & $\mathbf{N}$ & Median & Min & Max \\
\hline $\begin{array}{l}\text { Lama } \\
\text { imobilisasi }\end{array}$ & 67 & 6 minggu & 7 hari & 10 tahun \\
\hline
\end{tabular}

Lama imobilisasi pada penelitian ini didapatkan sangat bervariasi mulai dari hari, minggu, bulan hingga tahun. Lama imobilisasi paling singkat yang dapat menyebabkan ulkus yaitu 7 hari sebanyak 3 orang $(4,5 \%)$ dan lama imobilisasi terpanjang mencapai 10 tahun sebanyak 1 orang (1,5\%). Median lama imobilisasi pasien yang telah menderita ulkus dekubitus didapat selama 6 minggu sebanyak 2 orang (3\%).

\section{Penyakit Penyerta Pasien Geriatri dengan Ulkus Dekubitus}

Penelitian ini mendapatkan penyakit penyerta terbanyak adalah penyakit pada paru sebanyak 46 (68,6\%) pasien diikuti gangguan elektrolit sebanyak 41 pasien $(61,2 \%)$.

Tabel 5. Distribusi Penyakit Penyerta pada Pasien Geriatri dengan Ulkus Dekubitus

\begin{tabular}{lcc}
\hline \multicolumn{1}{c}{ Penyakit Penyerta } & f & \% \\
\hline Penyakit paru & 46 & 68,6 \\
Gangguan elektrolit & 41 & 61,2 \\
Malnutrisi & 22 & 32,8 \\
Gangguan hematologi & 21 & 31,3 \\
Penyakit ginjal & 18 & 26,8 \\
Sindroma delirium akut & 17 & 25,4 \\
Diabetes mellitus & 17 & 25,4 \\
Infeksi dan sepsis & 12 & 17,9 \\
\hline
\end{tabular}

\begin{tabular}{lcc}
\hline \multicolumn{1}{c}{ Penyakit Penyerta } & f & \% \\
\hline Hipertensi & 7 & 10,4 \\
Stroke & 4 & 6 \\
Keganasan & 4 & 6 \\
Penyakit kardiovaskular & 3 & 4,5 \\
Demensia & 3 & 4,5 \\
Epilepsi & 2 & 3 \\
Penyakit tulang dan sendi & 2 & 3 \\
\hline
\end{tabular}

\section{Pembahasan}

\section{Distribusi Pasien Geriatri dengan Ulkus Dekubitus berdasarkan Kelompok Usia dan Jenis Kelamin}

Hasil penelitian pada pasien geriatri dengan ulkus dekubitus yang dirawat di RSUP Dr. M. Djamil Padang tahun 2016 - 2019 didapatkan karakteristik pasien berdasarkan usia didominasi pada kelompok usia 60 - 69 tahun sebanyak 26 orang $(38,8 \%)$ kemudian kelompok umur $\geq 80$ tahun sebanyak 24 orang $(35,8 \%)$ dan kelompok umur $70-79$ tahun sebanyak 17 orang $(25,4 \%)$. Kondisi ini mungkin berhubungan dengan angka harapan hidup penduduk Indonesia secara umum mencapai 70,7 tahun dan didominasi oleh kelompok umur terbanyak berada pada $60-69$ tahun (usila muda) sebanyak 63,39\%.15,16 Berdasarkan data jumlah penduduk Kota Padang tahun 2019 menurut kelompok umur didapatkan usia lanjut dengan kelompok umur 60 - 69 tahun terbanyak dengan persentase $69 \% .{ }^{17}$ Hasil ini sejalan dengan hasil penelitian yang dilakukan oleh Nurul Latifa periode tahun 2017 menunjukkan bahwa jumlah pasien geriatri yang paling banyak ditemukan adalah kelompok umur 60 - 69 tahun yakni sebesar 56,8\%.18

Hasil ini berbeda dengan penelitian yang dilakukan di Jepang dimana salah satu faktor risiko terjadinya ulkus dekubitus adalah pasien berusia lebih dari 70 tahun yang memiliki risiko lebih tinggi untuk terjadinya ulkus dekubitus. ${ }^{19}$ Hal ini mungkin berhubungan dengan angka harapan hidup penduduk di Jepang lebih tinggi jika dibandingkan dengan Indonesia. Angka harapan hidup secara keseluruhan di Jepang mencapai 82,2 tahun. ${ }^{20}$ Usila memiliki risiko tinggi terjadi ulkus dekubitus akibat proses penuaan pada kulit sehingga terjadi penipisan epidermis dan dermis serta hilangnya lapisan papila dermis sebagai pelindung kulit sehingga kulit yang mengalami penuaan cenderung tidak dapat mengkompensasi adanya gesekan serta berkurangnya lapisan antara dermis dan 
epidermis sebagai tempat transpor oksigen dan nutrien. ${ }^{21}$

Karakteristik pasien berdasarkan jenis kelamin ditemukan lebih banyak perempuan dibanding laki-laki. Pasien berjenis kelamin perempuan berjumlah 50 orang $(74,6 \%)$ dari total keseluruhan 67 pasien. Hasil penelitian ini sejalan dengan penelitian yang dilakukan di RSUP Dr. M. Djamil tahun 2011-2013 yang mendapatkan 57\% pasien adalah perempuan. ${ }^{12}$ Begitu juga dengan penelitian yang dilakukan di RSUD Arifin Achmad Provinsi Riau tahun 2011-2013 didapatkan penderita ulkus dekubitus terbanyak adalah perempuan sebanyak $64.8 \%{ }^{14}$ Hasil yang sama didapatkan dari penelitian di RS Labuang Baji Makassar pada tahun 2013, jumlah penderita perempuan lebih banyak dibanding dengan lakilaki yaitu sebesar $58 \%{ }^{22}$ Hal ini berhubungan dengan jumlah penduduk usia lanjut yang berjenis kelamin perempuan di Indonesia lebih banyak dibanding laki-laki dikarenakan angka harapan hidup perempuan lebih tinggi daripada laki-laki. ${ }^{16}$ Selanjutnya, jumlah penduduk usia lanjut di kota Padang pada tahun 2019 didapatkan sebanyak $7,2 \%$ dan $3,8 \%$ nya adalah perempuan. ${ }^{17}$ Namun berbeda dengan hasil yang didapat di RSUP Dr. M. Djamil tahun 2015 tentang hubungan imobilitas dengan ulkus dekubitus yang mendapatkan pasien laki-laki (65,2\%) cenderung lebih banyak dibanding pasien berjenis kelamin perempuan. ${ }^{13}$

\section{Variasi Stadium Klinis Ulkus Dekubitus pada Pasien Geriatri}

Penelitian ini mendapatkan variasi stadium klinis ulkus dekubitus pada geriatri yang terbanyak didapatkan yaitu stadium 2 sebanyak 29 orang $(43,3 \%)$, stadium 3 sebanyak 15 orang $(22,4 \%)$ dan stadium ulkus yang tidak ada datanya dalam rekam medis sebanyak 14 orang $(20,9 \%)$. Hal ini mungkin berhubungan dengan kurangnya peran tenaga medis dan kurangnya pengetahuan keluarga pasien dalam memberikan perawatan berupa perubahan posisi dan skrining risiko ulkus dekubitus pada pasien yang berisiko maupun pada pasien yang sudah mendapat ulkus dekubitus sebelum masuk rumah sakit sehingga terabaikannya ulkus dekubitus stadium 1 dan baru ditemukan saat ulkus sudah stadium 2.23,24 Hasil penelitian ini sejalan dengan penelitian di RSUD Arifin Achmad tahun 2010 yang mendapatkan $33.3 \%$ ulkus dekubitus stadium 2 paling banyak dan muncul pada minggu pertama perawatan. ${ }^{25}$

Hasil penelitian ini berbeda dengan penelitian yang dilakukan di Hamburg yang mendapatkan distribusi stadium terbanyak pada stadium 1 dan berturut-turut semakin sedikit sampai ke stadium 4. ${ }^{8}$ Begitu juga hasil penelitian yang dilakukan di Kota Bandung yang mendapatkan stadium 1 sebagai stadium terbanyak bahkan mencapai $51,4 \%$ dan semakin tinggi stadium semakin sedikit jumlah penderitanya.10 Berdasarkan penelitian International Health Care Publications (IHCP) mendapatkan stadium 1 sebagai stadium terbanyak. ${ }^{26}$

\section{Penyebab Imobilisasi Pasien Geriatri dengan Ulkus Dekubitus berdasarkan Faktor Risiko}

Pada penelitian ini ditemukan penyebab imobilisasi terbanyak dari faktor risiko intrinsik atau yang berasal dari tubuh pasien itu sendiri. Penyakit neurologis menjadi penyebab imobilisasi terbanyak pertama dengan jumlah 26 orang, diikuti gangguan motorik sebanyak 15 orang, sedangkan penyebab imobilisasi berdasarkan faktor risiko ektrinsik didapat trauma sebanyak 2 orang dan post operatif hip replacement sebanyak 1 orang. Sebanyak 15 orang tidak diketahui penyebab imobilisasinya.

Hasil penelitian ini sesuai dengan penelitian di RSUD Arifin Achmad Pekanbaru yang mendapat diagnosis medis pasien yang berisiko terkena ulkus dekubitus terbanyak adalah kasus neurologis (80\%). ${ }^{27}$ Hasil ini juga sejalan dengan faktor risiko yang terdapat dalam buku Essentials of clinical geriatrics yang menyebutkan penyebab tersering imobilisasi pada pasien usia lanjut yaitu gangguan muskuloskeletal, gangguan neurologis, penyakit kardiovaskular, penyakit paru, gangguan sensoris, restrain fisik, malnutrisi, penyakit sistemik yang parah seperti keganasan,gangguan mental seperti depresi dan efek samping obatobatan. ${ }^{28}$ Salah satu penyakit neurologis terbanyak yang ditemukan adalah stroke. Stroke memberi efek fisik dan fungsional pada penderitanya sehingga pasien tidak bisa melakukan kegiatan sehari hari karena adanya kelemahan pada anggota gerak dan membuat pasien hanya terbaring atau hanya bisa duduk di kursi roda. Stroke merupakan salah satu Penyakit Tidak Menular (PTM) dengan kasus terbanyak di 
Indonesia, menurut Sistem Informasi Surveilans PTM di Indonesia didapatkan jumlah kasus mencapai 4.092 kasus di Puskesmas yang ada di Indonesia pada tahun 2016. Berdasarkan kelompok umur didapatkan $40,9 \%$ berada pada kelompok umur $\geq 60$ tahun yang merupakan lansia. Sedangkan berdasarkan data Sistem Informasi Rumah Sakit (SIRS), jumlah kasus stroke yang di rawat inap di Rumah Sakit Indonesia tahun 2015 mencapai 25.600 kasus dan hampir sama antara laki-laki (49,8\%) dan perempuan $(50,2 \%)$. Menurut kelompok umur, sebanyak 51,6\% kasus berada pada rentang umur 45-64 tahun dan $37,7 \%$ berusia $\geq 65$ tahun. ${ }^{29}$

Hasil penelitian ini berbeda dengan penelitian yang dilakukan di United States dimana didapatkan gangguan neurologis dengan insiden sebanyak 7-8\% sedangkan cedera tulang belakang terjadi sebanyak 25-66\%. ${ }^{26}$ Penelitian di RSUD Dr. Soetomo Surabaya didapatkan penyebab terbanyak ulkus dekubitus yang dihubungkan dengan beberapa penyakit penyebab imobilisasi seperti spinal cord injury, fraktur ekstremitas bawah, stroke, dan lain-lain. ${ }^{30} \mathrm{Hal}$ ini dikarenakan penyakit atau gangguan penyebab imobilisasi yang sangat beragam.

\section{Lama Imobilisasi pada Pasien Geriatru dengan Ukuran Dekubitus}

Lama imobilisasi pasien geriatri dengan ulkus dekubitus ditemukan sangat bervariasi mulai dari hari, minggu, bulan hingga tahun sesuai dengan stadium penderita. Lama imobilisasi paling singkat yang dapat menyebabkan ulkus yaitu 7 hari sebanyak 3 orang $(4,5 \%)$ dan lama imobilisasi terlama mencapai 10 tahun sebanyak 1 orang $(1,5 \%)$. Median lama imobilisasi pasien yang telah menderita ulkus dekubitus didapat selama 6 minggu sebanyak 2 orang (3\%). Hasil ini sesuai dengan penelitian di RSUD Arifin Achmad yang mendapatkan ulkus dekubitus paling banyak terjadi pada hari ke-7 setelah rawatan. ${ }^{14}$ Penelitian yang dilakukan di RSUP Dr. M. Djamil Padang mendapatkan onset ulkus dekubitus $\leq 2$ minggu rawatan. ${ }^{12}$ Durasi imobilisasi yang sangat bervariasi ini terjadi karena perbedaan perawatan yang didapat oleh masing-masing pasien. Kebanyakan dari pasien yang dirawat di rumah, umumnya mendapatkan stadium ulkus yang tinggi ketika didiagnosis di rumah sakit. Namun masih dibutuhkan penelitian lebih lanjut mengenai lama imobilisasi pada pasien geriatri dengan ulkus dekubitus.

\section{Penyakit Penyerta Pasien Geriatri dengan Ulkus Dekubitus}

Penelitian ini mendapatkan penyakit penyerta terbanyak adalah penyakit pada paru sebanyak 46 pasien, gangguan elektrolit sebanyak 41 pasien dan malnutrisi 22 pasien. Sesuai dengan penelitian di Jerman yang mendapatkan gangguan pada paru, penyakit kardiovaskular (oklusi arteri perifer dan gagal jantung kongestif), demensia dan diabetes mellitus sering menjadi penyakit penyerta pada ulkus dekubitus. ${ }^{8}$ Penelitian ini juga sesuai dengan penelitian di Jerusalem menemukan penyakit kronis seperti penyakit paru kronis, penyakit kardiovaskurlar, diabetes mellitus, ginjal, gangguan neurodenegeratif, kondisi kronis seperti malnutrisi, anemia, penyakit infeksi berulang sering ditemukan sebagai penyakit penyerta pada pasien geriatri dengan ulkus dekubitus. ${ }^{7}$

Imobilisasi dapat mengakibatkan komplikasi seperti terjadinya penurunan ventilasi, atelektasis, gangguan ginjal serta hiperkalsemia dan intoleransi glukosa. Imobilisasi lama juga meningkatkan risiko terjadinya edema pulmonal, terganggunya kemampuan untuk membersihkan sekresi tracheobronchial dan meningkatnya emboli paru. ${ }^{31}$ Diabetes melitus memiliki hubungan yang signifikan dengan insiden ulkus dekubitus karena mempengaruhi perfusi jaringan khususnya perifer dan memiliki mekanisme patogenik yang berhubungan dengan terjadinya ulkus seperti angiopati, neuropati, hipoksia dan hantaran neuropeptida yang abnormal. ${ }^{32}$

\section{Simpulan}

Berdasarkan hasil penelitian yang telah dilakukan terhadap pasien geriatri dengan ulkus dekubitus yang dirawat di RSUP Dr. M. Djamil Padang tahun 2016-2019 didapatkan bahwa pertama sebagian besar pasien geriatri dengan ulkus dekubitus pada kelompok umur 60-69 tahun (usila muda) dan berjenis kelamin perempuan. Kedua sebagian besar pasien geriatri dengan ulkus dekubitus berada pada stadium 2 (Partial-Thickness Skin Loss with Exposed Dermis). Ketiga sebagian besar pasien geriatri dengan ulkus dekubitus disebabkan oleh faktor intrinsik salah satu terbanyak adalah penyakit neurologis 
dan faktor ekstrinsik terbanyak adalah trauma. Keempat lama imobilisasi minimum ditemukan 7 hari dan maksimum 10 tahun. Median lama imobilisasi pasien didapatkan 6 minggu. Kelima sebagian besar penyakit penyerta yang dialami adalah penyakit paru.

\section{Ucapan Terima Kasih}

Terima kasih untuk semua pihak dan instansi yang telah membantu penelitian ini baik secara moril maupun materil terutama Bagian Instalasi Rekam Medis RSUP Dr. M. Djamil Padang dan pihak lainnya yang tidak dapat disebutkan satu per satu.

\section{Daftar Pustaka}

1. Medical Education Partnership (MEP). International guidelines pressure ulcer prevention prevalence and incidence. In: MacGregor L, editor. London. 2009.

2. Pranarka K. Buku ajar boedhi-darmojo geriatri (ilmu kesehatan usia lanjut). 5th ed. Martono H, Pranarka K, editors. Badan Penerbit FK UI. 2014;306.

3. National Library of Medicine. Pressure Ulcer: MeSH descriptor data 2018. Medical Subject Headings. https://meshb-

prev.nlm.nih.gov/record/ui?ui=D003668. diakses pada 30 Juni 2019

4. National Institute for Health and Excellence. Pressure ulcer. 2015;6-7.

5. Boyko T V, Longaker MT, Yang GP. Review of the current management of pressure ulcers. Adv Wound Care. 2016;7(2):57-67.

6. Jaul E. Assessment and management of pressure ulcers in the elderly current strategies. 2010;27(4):311-25.

7. Jaul E, Barron J, Rosenzweig JP, Menczel J. An overview of co-morbidities and the development of pressure ulcers among older adults. 2018;1-11.

8. Anders J, Heinemann A, Leffmann C, Leutenegger M, Pröfener F, Renteln-kruse W Von. Decubitus ulcers : Pathophysiology and primary prevention. 2010;107(21).

9. Min H, Tan J, Izzati N, Kamaruzzaman SB, Vyrn A, Poi $\mathrm{PJH}$, et al. Determinants of mortality among older adults with pressure ulcers. Arch Gerontol Geriatr. 2020;59(3):536-41.

10. Sari SP, Everink IH, Sari EA, Afriandi I, Amir Y, Lohrmann C, et al. The prevalence of pressure ulcers in community-dwelling older adults : A study in an Indonesian city. 2019;1-8.

11. Menteri Kesehatan Republik Indonesia. Peraturan menteri kesehatan Republik Indonesia nomor 79 tahun 2014 tentang penyelenggaraan pelayanan geriatri di rumah sakit. 2014.

12. Pratama DR. Gambaran faktor risiko ulkus dekubitus di RSUP Dr. M. Djamil Padang tahun 2011-2013. 2015.

13. Ananda D. Hubungan imobilitas dengan ulkus dekubitus pasien geriatri di RSUP. Dr. M. Djamil Padang. 2016.

14. Mutia L. Profil penderita ulkus dekubitus yang menjalani tirah baring di ruang rawat inap RSUD Arifin Achmad Provinsi Riau periode Januari 2011-
Desember 2013. J Online Mhs Fak Kedokt UNRI. 2015;2:1-11.

15. Kementrian Kesehatan RI. Analisis lansia di Indonesia. Jakarta: Pusat Data dan Informasi Kemenkes RI. 2017.

16. Silviliyana M, Maylasari I, Agustina R, Ramadani KD, Sulistyowati R, Annisa L, et al. Statistik penduduk lanjut usia 2018. Susilo D, Harahap IE, Sinang R, editors. Badan Pusat Statistik. 2018.

17. Dinas Kesehatan Kota Padang. Profil kesehatan tahun 2019. 2019.

18. Latifa N. Gambaran multipatologi pasien geriatri di rawat inap penyakit dalam RSUP DR. M. Djamil Padang periode 1 Januari-31 Desember 2017. 2019.

19. Kaitani T, Tokunaga K, Matsui N, Sanada H. Risk factors related to the development of pressure ulcers in the critical care setting. 2010;414-21.

20. CIA (Central Intellegence Agency). The world factbook: Life expectancy. https://www.cia.gov/library/publications/theworld-factbook/geos/ja.html diakses pada 22 Juni 2019

21. Mervis JS, Phillips TJ. Pressure ulcers : pathophysiology, epidemiology, risk factors, and presentation. J Am Dermatology. 2019;81(4):881-90.

22. Said S, Haskas Y, Semana A. Faktor yang mempengaruhi terjadinya dekubitus pada pasien yang dirawat di ruang ICU RS Labuang Baji Makassar. 2013;2:1-6.

23. Sulidah, Susilowati. Pengaruh tindakan pencegahan terhadap kejadian dekubitus pada lansia imobilisasi. Medisains. 2017;15(3):161-72.

24. Qaddumi JAS, Almahmoud O. Pressure ulcers prevalence and potential risk factors among intensive care unit patients in governmental hospitals in Palestine. Open Public Health J. 2019;12(1):121-6.

25. Citra BD, C. Sitompul H, Restuastuti T. Efektivitas alih baring tiap 2 jam terhadap pencegahan ulkus dekubitus pada pasien pasca stroke dengan tirah baring lama di bangsal saraf RSUD Arifin Achmad Pekanbaru. J Ilmu Kedokt. 2010;4(2):133.

26. Kirman CN. Pressure injuries (pressure ulcers) and wound care. Medscape. 2018;40-2.

27. Utomo W, Dewi YI, Abdurrasyid T. Efektivitas nigella sativa oil untuk mencegah terjadinya ulkus dekubitus pada pasien tirah baring lama. J Ners Indones. 2012;151-7.

28. Kane RL, Ouslander JG, Resnick B, Malone ML. Essentials of clinical geriatrics. 8th ed. New York; 2004. 245-78.

29. Mustikawati DE, Setyadi, Rosniuli S, Wahidin M, Jamaludin, Rainy Fathiyah. Profil penyakit tidak menular tahun 2016. Kemenkes RI 2017. 2017.

30. Huvi I. Profil klinik pasien dengan ulkus dekubitus di RSUD Dr Soetomo periode 1 Januari 2017-31 Desember 2017. 2017.

31. Rohman U. Perubahan fisiologis tubuh selama immobilisasi dalam waktu lama. J Sport Area. 2019;4(2):367-78.

32. Thomas E, Vinodkumar S, Mathew S, Setia MS. A study of the factors associated with risk for development of pressure ulcers. Indian J Dermatol. 2015;60(6):566-72. 